\title{
Article
}

\section{Characterization of Tensile Properties of Cola lepidota Fibers}

\author{
Rémy Legrand Ndoumou ${ }^{1,2}$, Damien Soulat ${ }^{1, *}{ }^{\circledR}$, Ahmad Rashed Labanieh ${ }^{1}\left(\mathbb{D}\right.$, Manuela Ferreira ${ }^{1}(0$, \\ Lucien Meva'a ${ }^{3}$ and Jean Atangana Ateba ${ }^{2}$ \\ 1 Laboratoire de Génie et Matériaux, Gemtex, Ensait, University of Lille, F-59000 Roubaix, France; \\ nbr10490@gmail.com (R.L.N.); ahmad.labanieh@ensait.fr (A.R.L.); manuela.ferreira@ensait.fr (M.F.) \\ 2 Laboratoire de Mécanique (LME), UFD SI, Université de Douala, Douala P.O. Box 24157, Cameroon; \\ aajean2003@yahoo.fr \\ 3 Laboratoire d'Ingénierie Civile et Mécanique, Université de Yaoundé I, Yaoundé P.O. Box 8390, Cameroon; \\ jrl67_mevaa@yahoo.com \\ * Correspondence: damien.soulat@ensait.fr
}

check for updates

Citation: Ndoumou, R.L.; Soulat, D.; Labanieh, A.R.; Ferreira, M.;

Meva'a, L.; Atangana Ateba, J.

Characterization of Tensile Properties of Cola lepidota Fibers. Fibers 2022, 10,

6. https://doi.org/10.3390/

fib10010006

Academic Editor: Carlo Santulli

Received: 9 November 2021

Accepted: 5 January 2022

Published: 12 January 2022

Publisher's Note: MDPI stays neutral with regard to jurisdictional claims in published maps and institutional affiliations.

Copyright: (c) 2022 by the authors Licensee MDPI, Basel, Switzerland. This article is an open access article distributed under the terms and conditions of the Creative Commons Attribution (CC BY) license (https:// creativecommons.org/licenses/by/ $4.0 /)$.

\begin{abstract}
Plant fibers are being increasingly explored for their use in engineering polymers and composites, and many works have described their properties, especially for flax and hemp fibers. Nevertheless, the availability of plant fibers varies according to the geographical location on the planet. This study presents the first work on the mechanical properties of a tropical fiber extracted from the bast of Cola lepidota (CL) plant. After a debarking step, CL fibers were extracted manually by wet-retting. The tensile properties are first identified experimentally at the fibers scale, and the analysis of the results shows the great influence of the cross-section parameters (diameter, intrinsic porosities) on these properties. Tensile properties of CL fibers are also predicted by the impregnated fiber bundle test (IFBT). At this scale of bundles, a hackling step, which reduces shives and contributes to the parallelization of the fibers within bundles, improves tensile properties predicted by IFBT. The comparison with the properties of plant fibers given in the literature shows that CL fibers have tensile properties in the same range as kenaf, flax or hemp fibers.
\end{abstract}

Keywords: Cola lepidota Fiber; plant fibers properties; fibers tensile methods; bio-based composite

\section{Introduction}

Due to their combination of environmental and technical performances, plant fibers are being increasingly explored and utilized in engineering polymers and composites, and the annual number of published works during the past ten years in the field of natural fiber-reinforced composites has been expanded by a factor of 3.5 [1,2]. Following a recent work, non-wood plant fibers can be classified into six types based on the parts where they are obtained from the plants as bast fibers (flax, hemp, jute, kenaf, nettle, okra, ramie), grass fibers (bamboo, elephant grass), leaf fibers (abaca, pineapple, pandanus, helicopus, sisal), seed/fruit fibers (coir, cotton cocoa, kapok, jatropha, palm), straw fibers (corn, rice, wheat), trunk, fronds and leaf sheats fibers (abaca, coconut tree, date palm, oil palm) [3]. Recent reviews describe, in detail, the biochemical contents and mechanical properties of these plant fibers [1-7]. It can be deduced from these works that the tensile properties of plant fibers differ, in a large range, between different fiber species and varieties and are greatly influenced by the variations in several factors such as plant location, their hierarchical structures, presence of defects, the water content of plant fibers and more recently, during the different steps applied after harvesting (retting, scutching, carding, hackling) [8-11]. The wide range of variability of these properties at fiber scale can also be explained by experimental uncertainties that negatively affect the accuracy of the results, such as the determination of the useful cross-section area [12,13], the determination of the overall deformation or the computation of elastic modulus after nonlinear regions $[3,6,14]$. Relative to the difficulties associated with conventional tensile testing at fiber scale (definition of 
the fiber cross-section area, individualization of samples, etc.), the use of impregnated fiber bundles to deduce the tensile properties of elementary fibers from the composite by back-calculation can be recommended (IFBT) [15]. Numerous studies on flax and hemp have compared the tensile properties obtained with these two methods in order to explain the sources of discrepancies $[3,8,14,16-18]$. These works have led to the standardization of experimental protocols, which can now be used for other local plant fibers. Indeed, the availability of natural fibers varies according to the geographical location on the planet, which is of interest to the environment since each industrial center can locate available resources and thus meet the demand for green materials while using new, accessible and low-cost tropical species [19]. Thus, works have focused on the study of the properties of new plant fibers such as those derived from pineapple leaves [20], okra stems [21], Sida cordifolia [22], Arundo donax [23], Lygeum spartum [24], Coccinia grandis [25], Markhamia lutea [26], Erythrina variegate [27] and Albizia Saman [28]. Concerning plant fibers issued from tropical plants in Central, East and West African countries, some studies are related to the identification of properties of African star apple leaves [29], Bast fibers of Triumfetta cordifolia [30] and Rhectophyllum camerunense fibers [31-33]. This paper concerns the mechanical properties of plant fiber extracted from the bark of Cola lepidota (CL) plant. Forty-two percent of Cameroon's surface area is covered with forests $(19,916,000$ ha in 2010 [34]). Tropical forests are an appropriate area for CL plant growth extended over the southern part of Cameroon, approximately 4,719,100 ha. A previous paper was focused on physico-chemical and thermal properties of these CL fibers [35], but without identification on mechanical properties. This experimental study aims to compare tensile properties identified with conventional tensile testing at fiber scale with those also identified on bundles with the IFBT method and also to analyze the influence on these tensile properties of a hackling manual step. Tensile properties of Cola lepidota Fibers are then compared with those of other plant fibers.

\section{Materials and Methods}

\subsection{Raw Materials}

\subsubsection{Plant Presentation}

Cola lepidota fiber $(C L)$ is extracted from the bast of Cola lepidota plant. It is a plant that belongs to the Sterculiaceae family and genus Cola. This shrub can reach $15 \mathrm{~m}$ in height and $25 \mathrm{~cm}$ in width [33]. Its stem is very slightly branched and humped and has a grey-green to brown coloring. According to Vivien et al. [36], it is possible to cultivate the plant and to harvest its fruit in the first year. Cola lepidota plant grows in tropical regions with a heavy humid climate.

\subsubsection{Extraction Process}

The bast of Cola lepidota was collected manually at Ebemewomen 2, District of Mvila South Region (Cameroon), in the month of April. Figure 1 shows the different steps of the CL fibers extraction process. During a first step (denoted barking in Figure 1), barks were firstly detached from the stem and exposed to the open air for two days. Then, they were immersed into a tank filled with water at ambient temperature $\left(24^{\circ} \mathrm{C}<\mathrm{T}<27^{\circ} \mathrm{C}\right)$ for four weeks. For fibers from plants growing in temperate climates (as flax, hemp), the influence of the dry-retting stage on the mechanical properties was previously studied [11]. The choice of water retting for CL fibers is linked to the very humid climate and is classical for fibers from plants growing in tropical forests as Okra or Napier grass [19]. After several steps of rinsing with clear water and drying fiber, bundles are then in the form of ribbons that can be stored in bales (denoted packaging in Figure 1). 


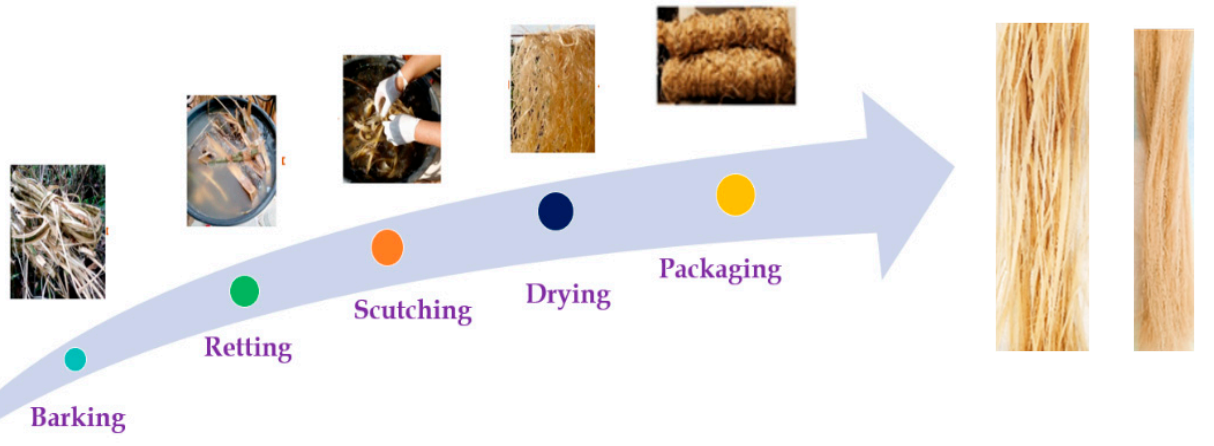

Figure 1. CL fiber extraction process: from bark to ribbons of fibers.

After these steps of barking, wet-retting, scutching and drying, the fibrous material is in a superposition of ribbons whose dimensions (length, width) depend on the debarking. A single ribbon has an average thickness of $100 \pm 12 \mu \mathrm{m}$. They are made up of highly interlocked bundles of fibers with grid rhombus structured (Figure 2c).

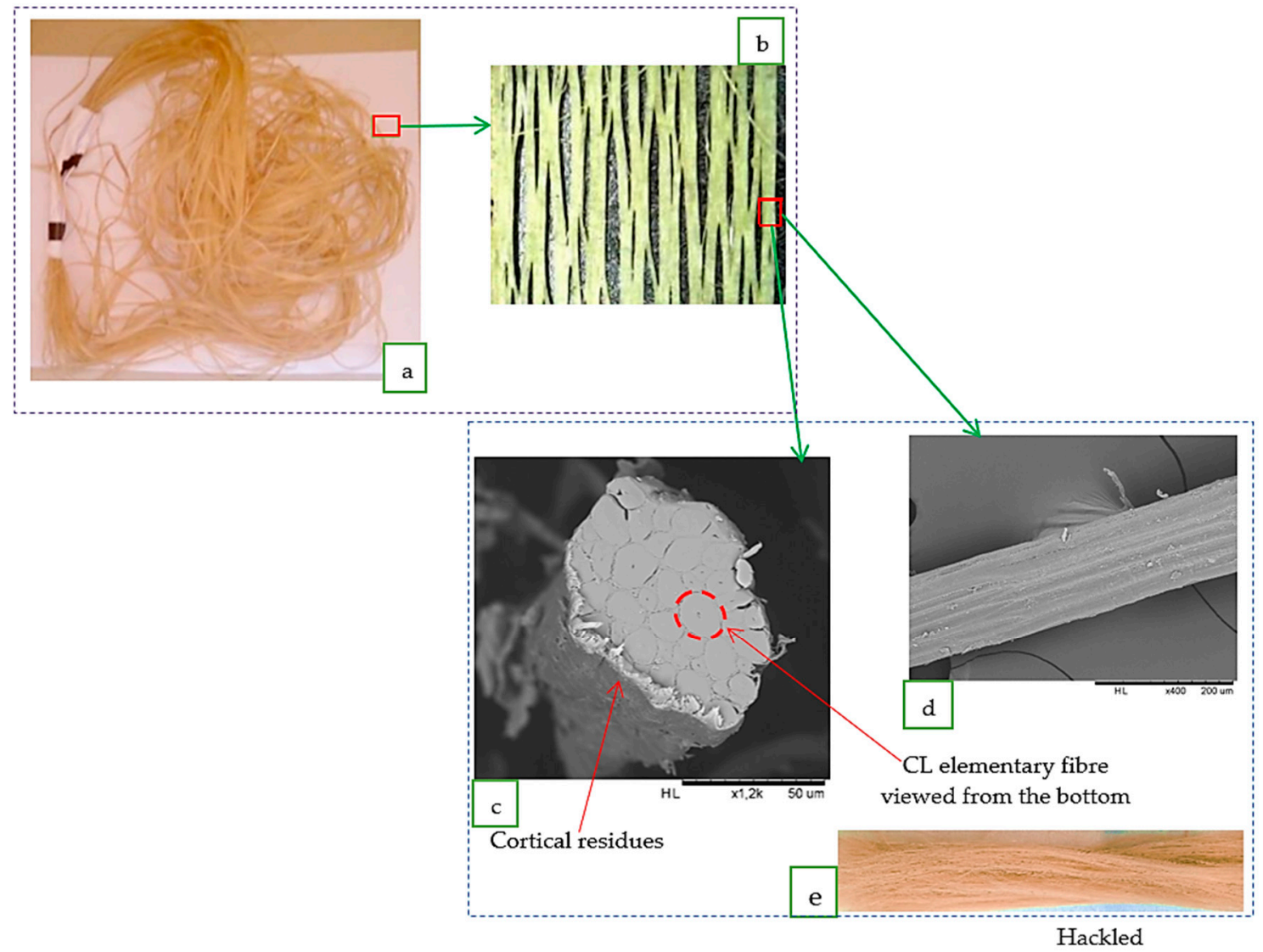

Figure 2. Multi-scale structure of $C L$ fibers: (a) CL fibers ribbons; (b) longitudinal view of CL fibers ribbons by Optical microscope; (c) SEM Cross section view CL fibers bundle; (d) SEM longitudinal view of CL fibers bundle; (e) hackled CL fibers bundles.

At a lower scale, CL fibers bundles are constituted of many elementary fibers bound together by middle-lamellae and surrounded by cortical residues.

In order to remove its impurities, individualize and parallelize the CL fibers, bundles are hackled thanks to a manual comb. Figure 2 shows the hierarchical structure of the ribbons at different scales. 


\subsection{Characterization Methods}

\subsubsection{Tensile Tests on Elementary CL Fibers}

Thirty technical CL Fibers were manually and carefully extracted from the bundles before hackling step, ensuring that the fibers were not damaged during this step. Before testing, single fibers were bonded onto a paper frame to obtain a fixed gauge length of $20 \mathrm{~mm}$. The mean diameter value of fiber was determined from ten measurements taken along the fiber with an optical microscope. Skewness and Kurtosis statistical tools were carried out to analyze the diameter distribution. From this measurement of the diameter, the calculation of the transverse section, assuming it to be circular, was made. For these cross-sectional estimations, two approaches were performed, taking into account, or not, the intrinsic porosity of CL fibers identified in a previous study [35].

In order to perform tensile tests, the paper frame was then clamped onto a universal MTS tensile testing machine equipped with a $10 \mathrm{~N}$ capacity load sensor and tested at a crosshead speed of $2 \mathrm{~mm} / \mathrm{min}$ according to the NFT 25-501 standard, which takes into consideration the compliance of the load sensor. Among the thirty fibers tested, four were not considered in the tensile behavior analysis due to slip failure during the tests. The Weibull statistical analysis, as described in [37], was used to evaluate the distribution of mechanical properties of these samples.

\subsubsection{Impregnated Fiber Bundle Tests (IFBT) on CL Fibers Bundles}

IFBT tests were conducted according to the method developed by the CELC [38] and described in [15] to evaluate the effective mechanical properties of fibers. IFBT specimens were prepared from CL fibers ribbons before and after the manual hackling step in order to analyze the influence of this step on the tensile properties. The CL fibers ribbons were previously oven-dried at $60{ }^{\circ} \mathrm{C}$ for $24 \mathrm{~h}$. IFBT specimens were manufactured with the GreenPoxy $56^{\circledR}$ epoxy resin and the SD SurfClear hardener from Sicomin ${ }^{\circledR}$ (Chateauneuf les Martigues, France), with a weight ratio of 100/37. The curing cycle occurred in a thermocompression press as described in [39]. Samples were then conditioned at room temperature for at least 7 days before testing. The fiber volume fraction of the impregnated bundle was determined based on both the volume and weight method using a density of $1.63 \mathrm{~g} / \mathrm{cm}^{3}$ for the CL fibers [35] and $1.16 \mathrm{~g} / \mathrm{cm}^{3}$ for the epoxy matrix. IFBT samples were mechanically tested with an Instron ${ }^{\circledR}$ tensile machine, with a load cell of $250 \mathrm{kN}$, a gauge length of $150 \mathrm{~mm}$, a width of $10 \mathrm{~mm}$ and a crosshead displacement rate of $1 \mathrm{~mm} / \mathrm{min}$. Digital image correlation (DIC) was used for the monitoring of the displacement during the test. Ten specimens in each configuration were tested, and SEM micrographs were performed to analyze the impregnation and fracture surface of samples. The tensile properties of CL fibers (stiffness and strength) are back-calculated from those of the IFBT samples using the rules of mixture following Equations (1)-(4). Two models were considered, the standard rule of mixture (denoted M1, Equations (1) and (2)) and the modified model (denoted M2, Equations (3) and (4)), which take into account the porosity level in IFBT samples, as described in $[40,41]$.

$$
\begin{aligned}
& E_{f}=\frac{E_{c}-E_{m} \times\left(1-V_{f}\right)}{V_{f}} \\
& \sigma_{f}=\frac{\sigma_{c}-\sigma_{m}^{\prime} \times\left(1-V_{f}\right)}{V_{f}} \\
& E_{f}=\frac{\frac{E_{c}}{\left(1-V_{p}\right)^{n}}-E_{m} \times V_{m}}{V_{f}} \\
& \sigma_{f}=\frac{\frac{\sigma_{c}}{\left(1-V_{p}\right)^{n}}-\sigma_{m}^{\prime} \times V_{m}}{V_{f}}
\end{aligned}
$$

with: E, V and $\sigma$ are, respectively, the modulus, volume fraction and stress; indexes $\mathrm{c}, \mathrm{m}$, $\mathrm{p}$ and $\mathrm{f}$ are composites, matrix, porosity and fiber, respectively. Considering the fact that 
fibers have a lower failure strain than the matrix and assuming a linear behavior of the resin [15]. The porosity factor, $n$, is considered equal to 2 [42]. Two moduli of CL fibers were back-calculated: $\mathbf{E}_{\mathbf{f} 1}$ between 0 and $0.1 \%$ of strain and $\mathbf{E}_{\mathbf{f} 2}$ between $0.3 \%$ and $0.5 \%$ of strain.

\section{Results and Discussion}

\subsection{Physical Properties of CL Fiber}

A statistical analysis of the distribution of technical fiber diameters shows a skewed and flattened distribution with a skewness (Sk) degree of -0.58 and a Kurtosis (Ku) degree of 0.34 . The average measured fiber diameter is $83.81 \mu \mathrm{m}$ with a coefficient of variation (CV) of $18.61 \%$. Compared to a study conducted on different varieties of flax fibers, this diameter is in the high range of values obtained [43].

The intrinsic porosity of CL fibers was previously measured to $13 \%$ [35]. This intrinsic porosity is in the range of that of hemp fibers and has a great influence on the stress concentrations and driving failure within a fiber [2]. This characteristic was considered to estimate the average technical fiber cross-section area.

\subsection{Tensile Properties of CL Fibers}

Figure 3a displays the average stress-strain curve and the evolution of the tangent modulus obtained from the tensile tests carried out on the 26 selected samples of CL fibers. For these curves, in Figure 3, the intrinsic porosity of CL fibers was not considered in the computation of the cross-section and mechanical properties. This curve exhibits nonlinear behavior as described in the literature for plant fibers $[2,6,11,14,16,18,44]$. Following the three different responses to tensile testing of unitary flax fibers by Lefeuvre et al. [18], this curve could be associated with type II with two linear parts separated by a yield point associated with a stick-slip mechanism. The evolution of the tangent modulus shows well around $1.5 \%$ of strain (Yield point), the significant decrease in the tangent module. In the second linear part, the tangent modulus seems very close to that of the first linear part. Associated with this gauge length and the diameter range measured experimentally, the tenacity of CL fibers can be estimated between 28 and $88.3 \mathrm{cN} / \mathrm{Tex}$.

Figure $3 c$ shows the evolution of stress at break and modulus (in the strain range of $0.3-1 \%$ ) with the diameter range identified experimentally for this batch of CL fibers. Both parameters decrease obviously with fiber diameter, as described for flax fibers by Baley et al. [14]. This evolution also shows a high dispersion between CL fibers (by their diameter) which can also come from intrinsic fibers defects or from the individualization stage. This high dispersion of CL fiber properties leads to the use of the Weibull distribution analysis tool in order to take into account the property variation factors on the assessment of the failure probability of CL fibers.

Figure $3 b$ shows the curve of the two-parameter Weibull distribution of the tensile strength, with Pr the probability of failure of fiber. We noted that experimental data dots (in purple in Figure $3 b$ ) fit a linear regression with an $\mathbf{R}^{2}$ value of $93.3 \%$. The shape parameter $(\mathbf{m})$ and strength characteristic $\left(\boldsymbol{\sigma}_{\mathbf{0}}\right)$ found are equal to 3.29 and $1049 \mathrm{MPa}$, respectively. The low value of $\mathbf{m}(<4)$ confirms the scattered results and the occurrence of defects in CL fibers. According to E. Trujillo and al [45], the shape parameter $\mathbf{m}$ is between 1 and 6 for natural fibers and between 5 and 15 for man-made fibers.

Table 1 compares these Weibull parameters with those described in the literature and associated with some other plant fibers studied $[31,45,46]$. In this Table 1 , the Weibull distribution analysis is applied on the stress at break and for CL fibers without taking into account the porosity in the computation of the cross-section. It is important to mention that, in this comparative table, the data extracted from the literature were not obtained with the same gauge length, which has an influence on the stress at break, as described by Sarasini et al. [19]. In the previous study, the crystallinity index of CL fibers was estimated to be $42 \%$ [35]. Wang et al. [47] studied the correlation degrees between the fiber tensile strength and the fiber chemical composition for kenaf fibers. A crystallinity in the range 
of $40-48 \%$ was found to be very close to those of CL fibers and for an equivalent tensile strength (Table 1).

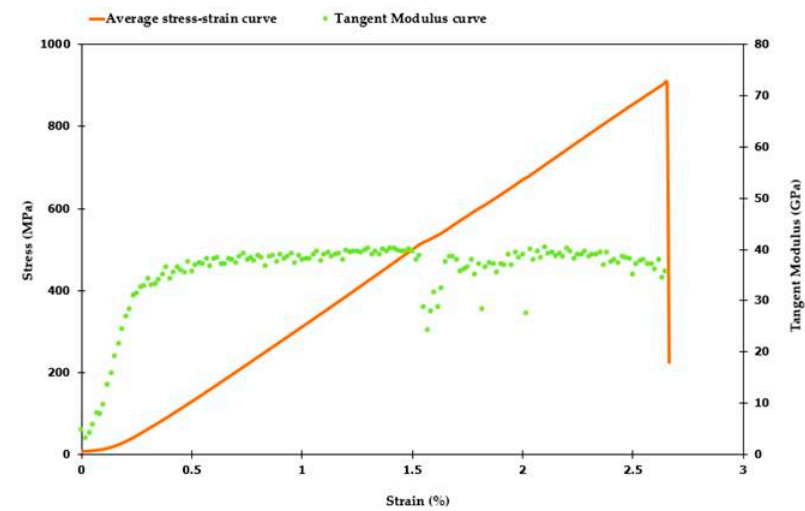

(a)

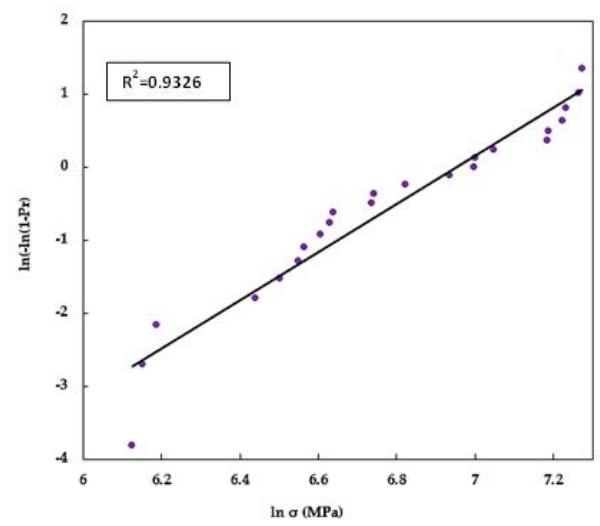

(b)

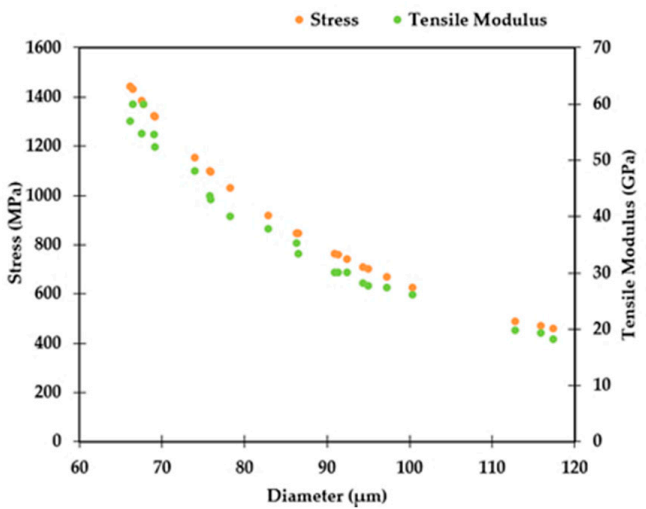

(c)

Figure 3. (a) Typical stress-strain curve and evolution of the tangent modulus. (b) Weibull distribution of stress at break. (c) Tensile modulus and stress at the break as a function of diameter measurement.

Table 1. Weibull distribution parameters for plant fibers.

\begin{tabular}{|c|c|c|c|c|c|c|}
\hline \multirow[b]{2}{*}{ Fibers } & \multirow[b]{2}{*}{$\begin{array}{l}\text { Extraction } \\
\text { Method }\end{array}$} & \multirow[b]{2}{*}{$\begin{array}{l}\text { Loading } \\
\text { Rate } \\
\text { (mm/min) }\end{array}$} & \multirow[b]{2}{*}{$\begin{array}{c}\text { Gauge } \\
\text { Length } \\
(\mathrm{mm})\end{array}$} & \multicolumn{2}{|c|}{ Weibull Parameters } & \multirow[b]{2}{*}{ References } \\
\hline & & & & $\begin{array}{c}\text { Shape } \\
\text { Parameter } \\
\text { (m) }\end{array}$ & $\begin{array}{c}\text { Scale } \\
\text { Parameter } \\
\sigma_{0}(\mathrm{MPa})\end{array}$ & \\
\hline $\begin{array}{l}\text { Rhectophyllum } \\
\text { Camerunense }\end{array}$ & $\begin{array}{c}\text { Water retted } \\
\text { manual extraction }\end{array}$ & 20 & 23 & 1.696 & 624.3 & {$[31]$} \\
\hline Flax & Green & 1 & 10 & 3.3 & 1356 & \\
\hline Hemp & $\begin{array}{c}\text { Water retted } \\
\text { manual extraction }\end{array}$ & 0.5 & 10 & 4.2 & 745 & {$[45]$} \\
\hline \multirow{2}{*}{ Sisal } & \multirow{2}{*}{$\begin{array}{l}\text { Decortication } \\
\text { mechanical process }\end{array}$} & \multirow{2}{*}{0.1} & 10 & 4.6 & - & \\
\hline & & & 20 & 3.7 & - & \\
\hline Bamboo & Manual & 1.3 & 80 & 2.9 & 228.2 & \\
\hline \multirow{2}{*}{ Kenaf } & \multirow{2}{*}{$\begin{array}{c}\text { Alkali 5\% } \\
90 \mathrm{mn} / 95^{\circ} \mathrm{C}\end{array}$} & \multirow{2}{*}{1} & 10 & 3.69 & 1010 & \multirow{2}{*}{ [46] } \\
\hline & & & 20 & 3.74 & 786.32 & \\
\hline CL & $\begin{array}{c}\text { Water retted } \\
\text { manual extraction }\end{array}$ & 2 & 20 & 3.29 & 1049 & $\begin{array}{l}\text { this } \\
\text { study }\end{array}$ \\
\hline
\end{tabular}


In Table 2, the tensile properties of CL fibers are compared with those of other plants fibers. For CL fibers, the intrinsic porosity of the fibers is taken into account (denoted $\mathrm{CL}_{2}$ ), or not (denoted $\left.\mathrm{CL}_{1}\right)$ in the evaluation of the cross-section and consequently on the tensile properties. Specific tensile properties were also added for these data from the literature.

Table 2. Comparison of properties of CL fibers to others plant fibers.

\begin{tabular}{|c|c|c|c|c|c|c|c|}
\hline \multirow[b]{2}{*}{ Fibers } & \multirow{2}{*}{$\underset{(\mu \mathrm{m})}{d}$} & \multirow{2}{*}{$\begin{array}{c}E \\
(\mathrm{GPa})\end{array}$} & \multirow{2}{*}{$\begin{array}{c}\sigma_{\mathrm{r}} \\
(\mathrm{MPa})\end{array}$} & \multirow{2}{*}{$\begin{array}{c}\mathcal{E}_{\mathrm{r}} \\
(\%)\end{array}$} & \multicolumn{2}{|c|}{ Specific Properties } & \multirow[b]{2}{*}{ References } \\
\hline & & & & & $\begin{array}{c}\sigma_{\mathbf{r}} / \rho \\
\left(\mathrm{Mpa} / \mathrm{g} \cdot \mathrm{cm}^{-3}\right)\end{array}$ & $\begin{array}{c}\mathrm{E} / \rho \\
\left(\mathrm{Gpa} / \mathrm{g} \cdot \mathrm{cm}^{-3}\right)\end{array}$ & \\
\hline $\begin{array}{l}\text { Rhectophyllum } \\
\text { Camerunense }\end{array}$ & 0.947 & $2.3-17$ & 150-1738 & $10.9-53$ & 588.3 & 6.1 & [31] \\
\hline Kenaf & - & 41 & 745-930 & 1.6 & $620.8-775$ & 34 & [46] \\
\hline Banana & $10-30$ & 12 & $12-30$ & $1.5-9$ & $8.8-22$ & 8.8 & \\
\hline Bamboo & $25-40$ & $11-32$ & $140-800$ & $2.5-3.7$ & $127-727$ & 10-29 & [48] \\
\hline Flax & $12-600$ & $27.6-80$ & $500-1500$ & $1.2-3.3$ & $333-1000$ & $18.4-53.3$ & \\
\hline Palf & - & 71 & $1020-1600$ & 0.8 & $680-1066$ & 47.3 & \\
\hline Sisal & $157-319.2$ & $4.7-20.5$ & $296.6-410.4$ & $2.4-4$ & 208.8-289 & $3.3-14.4$ & [49] \\
\hline Hemp & $13.7-25.8$ & $31-65$ & $182-1282$ & $1.9-3.5$ & $392.6-822.2$ & 33.3 & [11] \\
\hline $\mathrm{CL}_{1}$ & $66.2-117.4$ & $18.2-60$ & $457.6-1440$ & $2.4-2.6$ & $280-883$ & $11.6-36.8$ & This \\
\hline $\mathrm{CL}_{2}$ & $66.2-117.4$ & $22.2-66.89$ & $526-1655$ & $2.4-2.6$ & $322.7-1015$ & $13.6-41$ & study \\
\hline
\end{tabular}

From these tests performed at the scale of elementary fibers, before hackling step, and when the intrinsic porosity is not considered ( $\mathrm{CL}_{1}$, in Table 2), CL fibers had a tensile strength and modulus of $941 \pm 318 \mathrm{MPa}$ and $38.13 \pm 13.17 \mathrm{GPa}$, respectively. If we consider the intrinsic porosity $\left(\mathrm{CL}_{2}\right.$, in Table 2$)$, these properties increase with values of $1074 \pm 364 \mathrm{MPa}$ for the tensile strength and of $43.6 \pm 14.85 \mathrm{GPa}$ for the tensile modulus. The coefficient of variation (CV) is around $35 \%$ for both modulus and strength. Compared to others plant fibers, CL fibers have tensile properties in the same range as kenaf, flax or hemp fibers.

\subsection{Tensile Properties of CL Bundles by IFBT Method}

\subsubsection{Properties of the IFBT Samples}

IFBT samples were manufactured, as described in the previous section, from hackled and non-hackled CL fibers bundles, respectively. Fibers and porosities contents were evaluated by gravimetric method and are given in Table 3. These values are the average of ten IFBT specimens. Fibers volume fractions reached are in the range of those obtained by Samouh et al. [50] and Lansiaux et al. [51] on IFBT specimens made of sisal and flax yarns with the same resin and same manufacturing method, respectively.

Table 3. Porosities $\left(\mathbf{V}_{\mathbf{p}}\right)$ and fibers $\left(\mathbf{V}_{\mathbf{f}}\right)$ volume fractions in IFBT samples.

\begin{tabular}{ccc}
\hline IFBT Samples & $\begin{array}{c}\mathbf{V}_{\mathbf{f}} \\
\mathbf{( \% )}\end{array}$ & $\begin{array}{c}\mathbf{V}_{\mathbf{p}} \\
\mathbf{( \% )}\end{array}$ \\
\hline Hackled CL bundles & $52.8 \pm 2.33$ & $7.9 \pm 1.95$ \\
Non-hackled CL bundles & $51.6 \pm 1.53$ & $17.4 \pm 4.2$ \\
\hline
\end{tabular}

Samples manufactured with hackled CL fibers bundles show much lower porosities content than for the samples manufactured from non-hackled CL fibers bundle, which can be attributed to the alignment of the fibers that allows a better impregnation. For this range of fibers volume fraction, Lecoublet et al. [52] showed the influence of retting level on fiber surfaces of flax fibers and consequently on the porosities content.

SEM micrographs of fracture surface at four different magnifications $(\times 100, \times 350$, $\times 1000$ and $\times 2500$ from left to right on Figure 4 ) were made on IFBT samples manufac- 
tured from hackled and non-hackled CL fibers bundles, respectively. CL fibers are well embedded by resin. The magnification levels indicate cohesive fiber breakage. Fibers failed approximately in the same plane as the matrix.

(a)
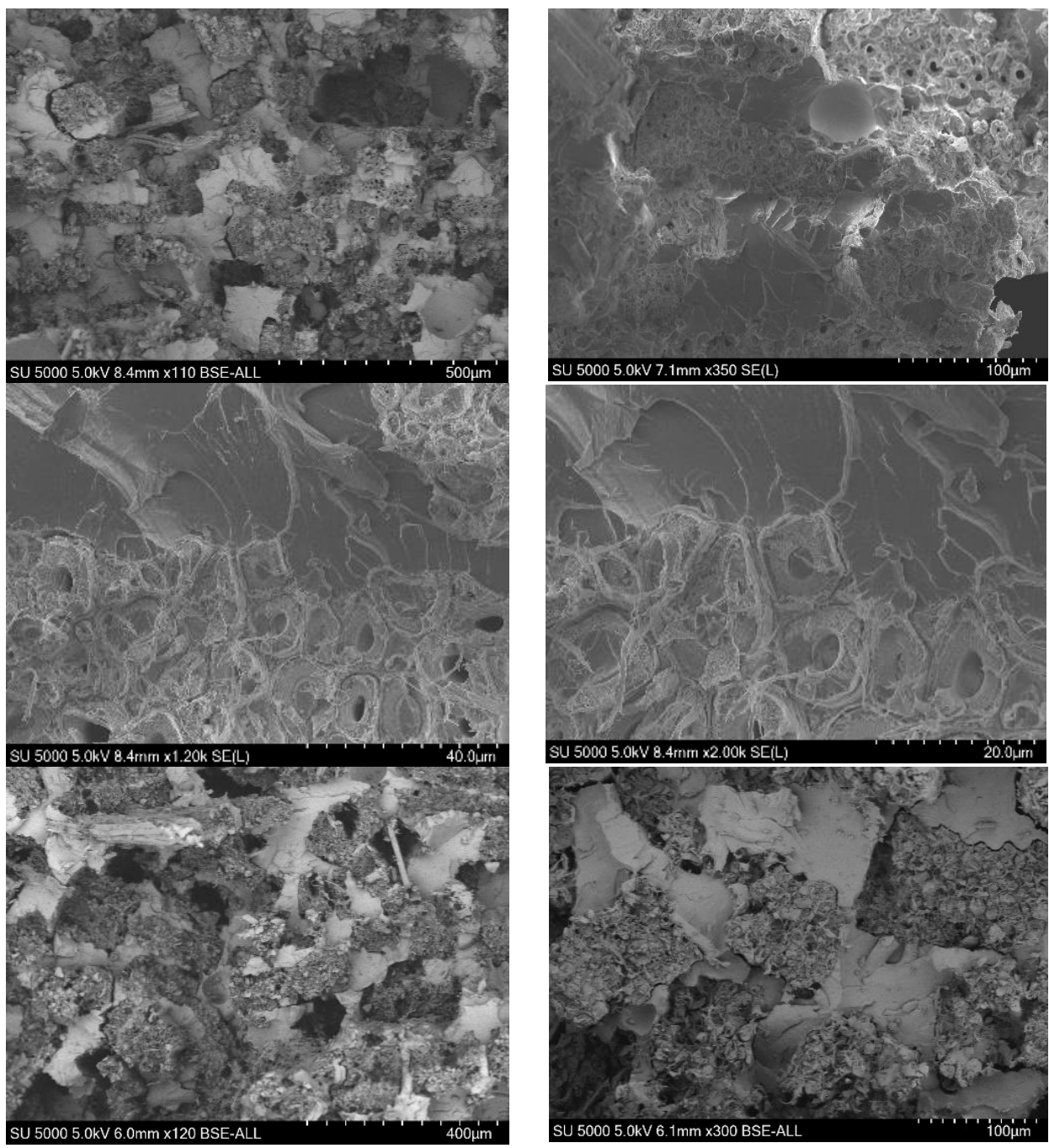

(b)
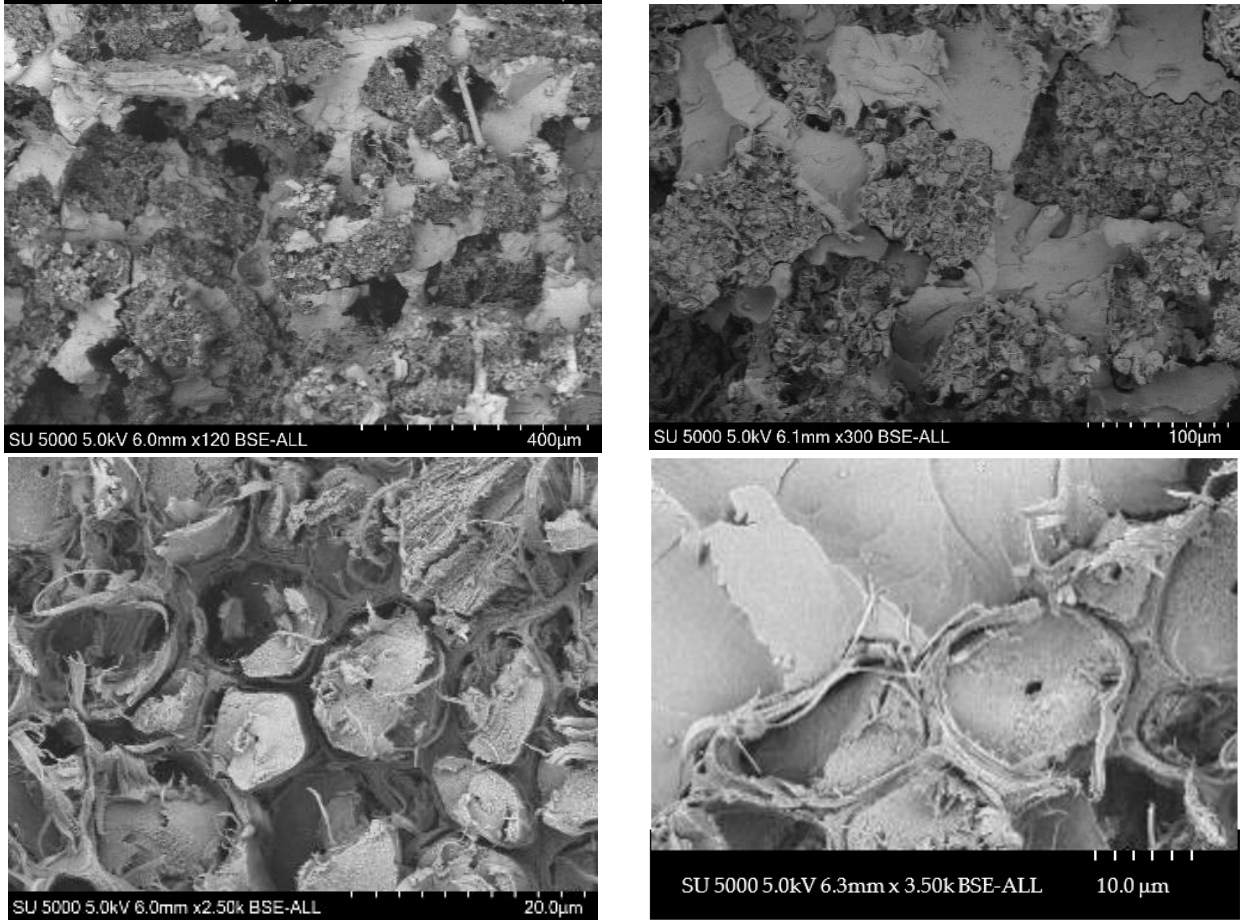

Figure 4. SEM micrographs of fracture surface at four different magnifications. (a) Hackled CL fibers and (b) non-hackled CL fibers.

\subsubsection{Tensile Properties of the IFBT Samples}

The results of the tensile characterization of the IFBT samples are presented in Figure 5 and in Table 4. 


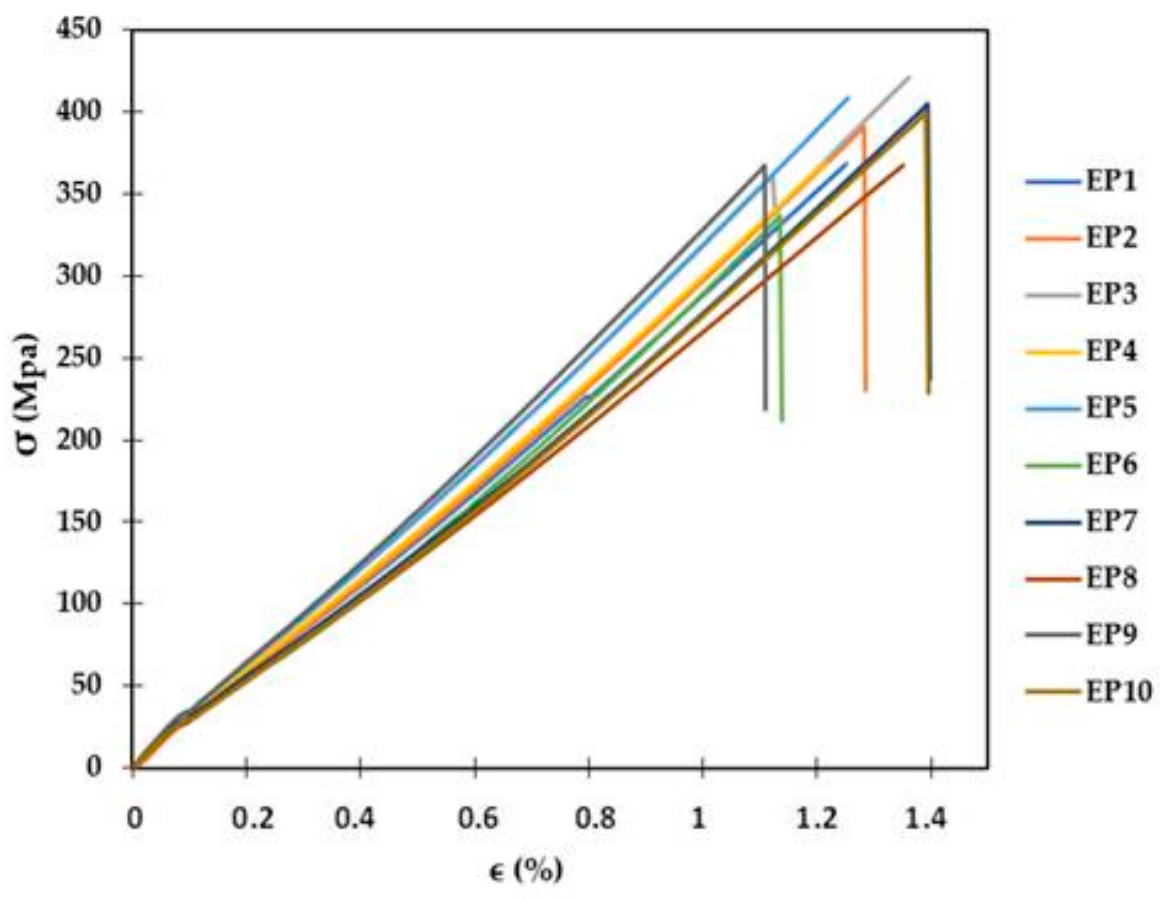

(a)

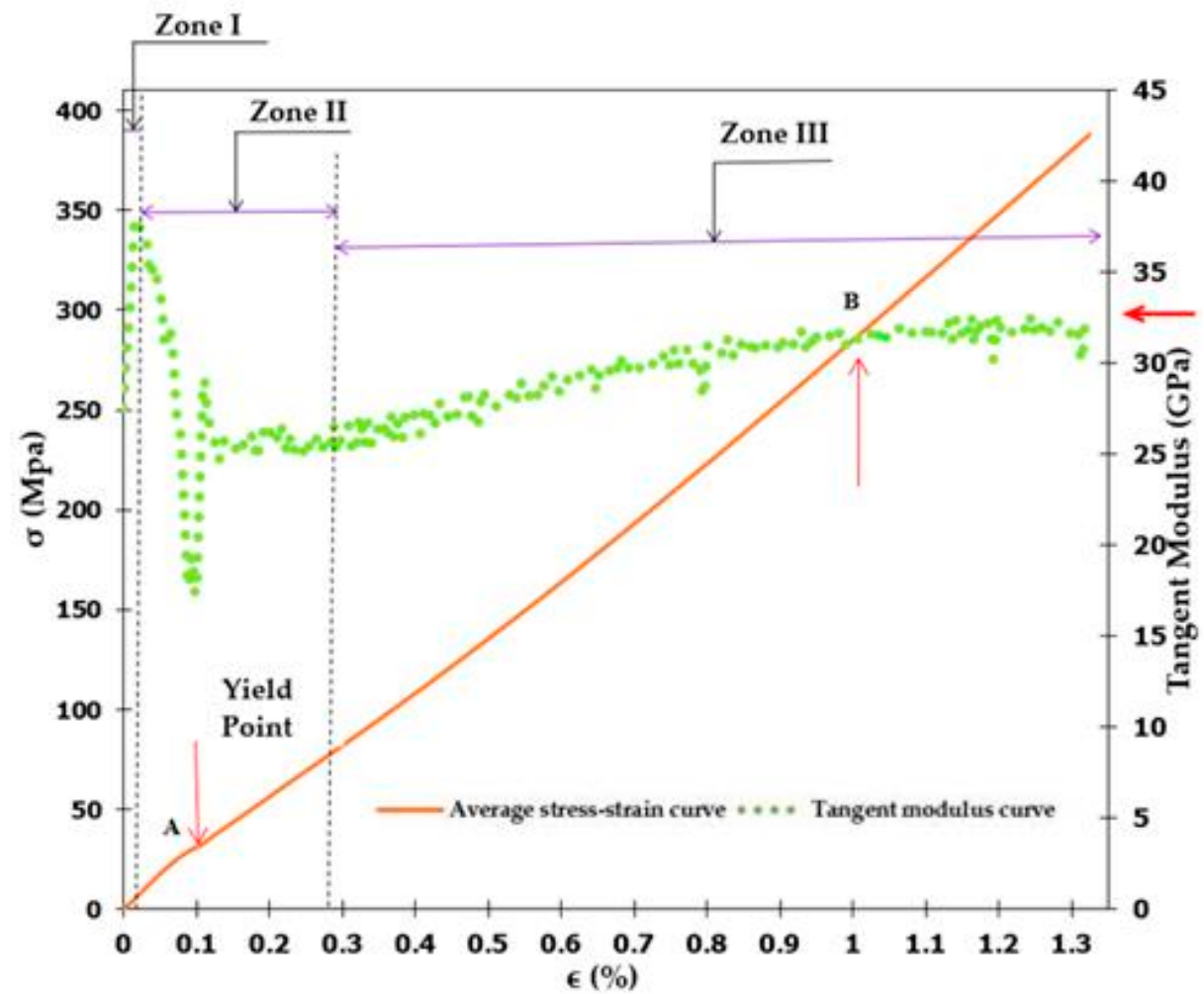

(b)

Figure 5. Tensile properties of IFBT samples from hackled CL fibers bundles: (a) Tensile stress-strain curves of the 10 specimens; (b) evolution of the average tangent modulus. 
Table 4. Tensile properties of IFBT specimens.

\begin{tabular}{cccc}
\hline $\begin{array}{c}\text { IFBT } \\
\text { Specimen }\end{array}$ & $\begin{array}{c}\mathbf{E}_{\mathbf{1}} \\
(\mathbf{G P a})\end{array}$ & $\begin{array}{c}\mathbf{E}_{\mathbf{2}} \\
(\mathbf{G P a})\end{array}$ & $\begin{array}{c}\boldsymbol{\sigma}_{\mathbf{r}} \\
\mathbf{( M P a )}\end{array}$ \\
\hline Hackled CL fibers & $33.77 \pm 3.11$ & $27.61 \pm 2.37$ & $394 \pm 21$ \\
non-hackled CL fibers & $28.44 \pm 3.68$ & $23.86 \pm 1.45$ & $267 \pm 47$ \\
\hline
\end{tabular}

Figure $5 \mathrm{a}, \mathrm{b}$ shows the tensile stress-strain curves of the ten IFBT samples made from hackled CL fibers and the evolution of the average tangent modulus as a function of strain, respectively.

The tensile stress-strain curves of the different specimens have the same trend with higher dispersions near the stresses at breaking. These curves exhibit the typical biphasic behavior observed for composites reinforced with natural fibers $[39,53]$.

In the first phase, the material behavior is quasi-linear until the yield point, located approximately at $35 \mathrm{MPa}$ and at a strain of $0.11 \%$. After an intermediate zone around this yield point, the second quasi-linear phase shows a reduced slope, thus indicating a lower stiffness of the material. The evolution of the tangent modulus (Figure $5 b$ ) function of strain can be classified in three stages: a first increase up to the yield point (between 0 and $0.11 \%$ of strain), followed by a significant decrease in the tangent modulus. In the third zone, up to failure, the tangent modulus increases slowly to reach a constant value. A related outcome was reported in the literature in a study of biocomposites reinforced with hemp fibers [24].

Table 4 summarizes the tensile properties (stress at break and moduli) of the IFBT samples made from hackled and non-hackled CL fibers bundles for the fibers volume fractions given in Table 3. The moduli are computed between 0 and $0.1 \%$ of strain and between $0.3 \%$ and $0.5 \%$ of strain, respectively.

These values in Table 4 show a significant effect of hackling step, especially on the stress at failure with an increase of $32 \%$ between average value reached by samples made from hackled CL fibers bundles compared to the value obtained with samples made from non-hackled CL fibers bundles. These results also show that the coefficient of variation on this strength decreases from $17.6 \%$ to $5.31 \%$ with hackling step. The lower porosities level of IFBT samples made from hackled CL fibers bundles can also be an explanation. Hackling step has not an influence on the softening of the tensile behavior, quantified by the ratio of moduli $\left(E_{2} / E_{1}\right)$ and which remains in the same range for both configurations

\subsubsection{Tensile Properties of CL Fibers Back-Calculated}

Figure 6 shows the CL fibers' tensile modulus back-calculated from the tensile results obtained on IFBT samples. These properties are computed with the two different models taking into account (denoted M2, Equation (3)) or not (denoted M1, Equation (1)) the porosities level on IFBT samples (Table 3 ) and for hackled CL fibers (Figure 6a) and nonhackled CL fibers (Figure $6 \mathrm{~b}$ ). 


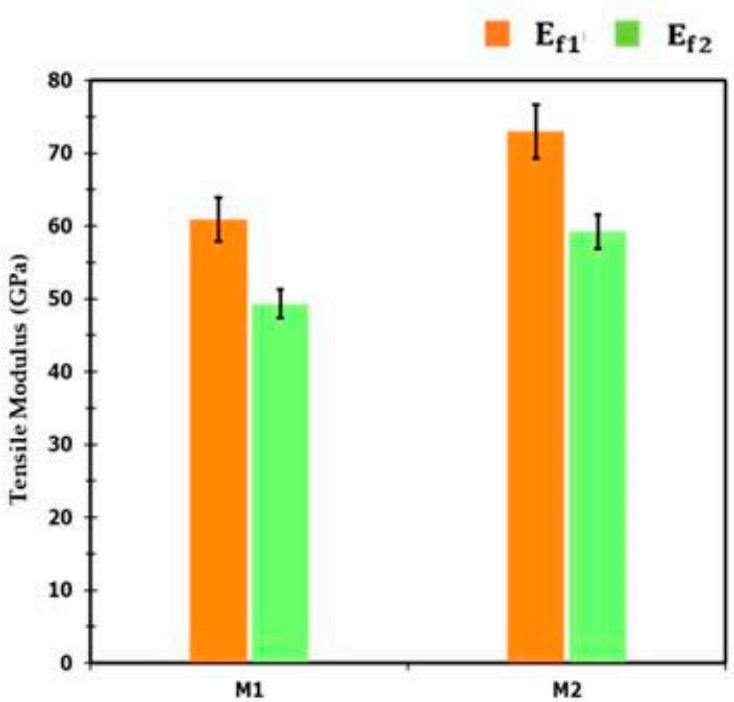

(a)

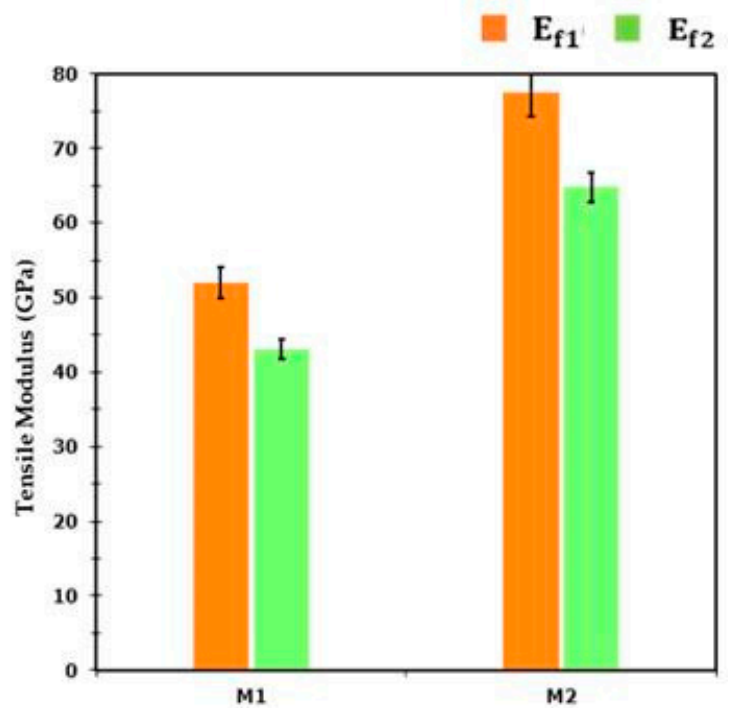

(b)

Figure 6. Tensile modulus of CL fibers back-calculated by the two models: (a) Hackled CL Fibers and (b) non-hackled CL fibers.

As described for sisal fibers [50], when using the modified rule of mixture (model M2) to take into account the level of porosities of IFBT samples result in a higher value of fiber modulus than those back-calculated with the classical rule of mixture (model M1). This difference is more significant for non-hackled CL fibers because the porosity level is much higher. If at the composite scale (Table 4 ) the second modulus $\left(\mathbf{E}_{2}\right)$ was quite close to the first modulus $\left(\mathbf{E}_{\mathbf{1}}\right)$, at the fiber scale, the difference is more significant (around $10 \mathrm{GPa}$ ) whatever the model used or the hackling step. It is a consequence of the back-calculation where a small variation at the composite scale can lead to larger differences at the fiber scale.

Compared to the stress at break, the hackling step has less influence on modulus at the scale of IFBT samples (Table 4). For the properties, at the scale of CL fibers, especially those back-calculated with the model M1, the difference between the modulus of hackled fibers and non-hackled is more significant (around 16\%). Hackling step reduces shives and dust and also contributes to the parallelization of the bundles' fibers, which improves the quality of impregnation (Figure $4 \mathrm{~b}$ ) and may explain the slight increase in modulus observed for hackled CL fibers compared to those for non-hackled CL fibers.

\subsection{Comparison of Tensile Properties of Non-Hackled CL Fibers}

As previously described, the experimental stress-strain curve (Figure 3a) obtained on non-hackled CL fibers has two linear parts. In order to compare the tensile modulus of CL fibers between values experimentally identified and those back-calculated from the IFBT method, the second modulus was selected $\left(\mathrm{E}_{\mathrm{f} 2}\right)$ in Table 5 . This choice was made because the evolution of modulus values is important at the beginning of loading, as illustrated in Figures $3 \mathrm{a}$ and $5 \mathrm{a}$. Experimental properties are given in Table 5 depending on whether $\left(\mathrm{CL}_{2}\right)$ or not $\left(\mathrm{CL}_{1}\right)$ the intrinsic porosity is taken into account in the computation of the cross-section. For tensile properties of CL fibers predicted by IFBT methods, values are given in Table 5 using the classical rule of mixture (IFBT-M1, Equations (1) and (2)) or taking into account porosities level of IFBT samples with the modified rule of mixture (IFBT-M2, Equations (3) and (4)). These predicted properties concern non-hackled CL fibers to be compared with those identified experimentally. 
Table 5. Tensile properties of CL fibers. Comparison between experimental and predicted values.

\begin{tabular}{ccc}
\hline & $\begin{array}{c}\mathbf{E}_{\mathbf{f}} \\
(\mathbf{G P a})\end{array}$ & $\begin{array}{c}\boldsymbol{\sigma}_{\mathbf{f}} \\
\mathbf{M P a})\end{array}$ \\
\hline $\mathrm{CL}_{1}$ & $38.13 \pm 13.17$ & $941 \pm 318$ \\
$\mathrm{CL}_{2}$ & $43.6 \pm 14.85$ & $1074 \pm 364$ \\
IFBT-M1 & $43.11 \pm 4.15$ & $708 \pm 41$ \\
IFBT-M2 & $64.78 \pm 4.56$ & $850 \pm 32$ \\
\hline
\end{tabular}

Concerning the strength of CL fibers, as described in previous works on flax $[3,15,54]$ or hemp fibers [11], values measured experimentally are significantly higher than those predicted by the IFBT method, even if the large standard deviations obtained experimentally lead to stress values in the same range as those predicted (around $700 \mathrm{Mpa}$ ). Shah et al. [55] discussed the sources of these discrepancies, related to experimental errors, suitability in the rule of mixture for stress at break and also the scale of the experiment. A comparison at the same scale, between tensile stress at break identified on an assembly of fiber bundles, as described in [14], with those predicted by the IFBT method might be more suitable.

Concerning the modulus of CL fibers, values obtained experimentally and backcalculated by the initial rule of mixture (IFBT-M1) are very close, especially when the intrinsic porosities of $\mathrm{CL}$ fibers are considered $\left(\mathrm{CL}_{2}\right)$ and give a modulus around $43 \mathrm{GPa}$. These properties identified by both methods are then compared in Table 6 to those of some plant fibers. CL fibers have tensile properties of the same order as those of flax, hemp or sisal fibers presented in the literature.

Table 6. Comparison between CL fibers properties with those of plant fibers predicted by IFBT method or identified experimentally.

\begin{tabular}{|c|c|c|c|c|}
\hline Fibers & Method & $\begin{array}{c}\mathrm{E}_{\mathrm{f}} \\
(\mathrm{GPa})\end{array}$ & $\begin{array}{c}\sigma_{\mathrm{f}} \\
(\mathrm{MPa})\end{array}$ & References \\
\hline Flax & $\begin{array}{l}\text { experimental } \\
\text { IFBT }\end{array}$ & $\begin{array}{l}44.5 \pm 14 \\
40.8 \pm 3,5\end{array}$ & $\begin{array}{c}791 \pm 319 \\
527 \pm 138\end{array}$ & [15] \\
\hline Sisal & $\begin{array}{l}\text { experimental } \\
\text { IFBT }\end{array}$ & $\begin{array}{c}12.5 \pm 7.8 \\
17.02 \pm 3.74\end{array}$ & $\begin{array}{c}340.02 \pm 70.4 \\
-\end{array}$ & [50] \\
\hline $\begin{array}{c}\text { Hemp } \\
\text { (SANTHICA } 27 \text { R0) }\end{array}$ & $\begin{array}{l}\text { experimental } \\
\text { IFBT }\end{array}$ & $\begin{array}{c}48 \pm 17 \\
50.3 \pm 12\end{array}$ & $\begin{array}{l}732 \pm 550 \\
384 \pm 225\end{array}$ & [11] \\
\hline $\begin{array}{c}\text { Hemp } \\
\text { (FUTURA } 75 \text { R0) }\end{array}$ & $\begin{array}{l}\text { experimental } \\
\text { IFBT }\end{array}$ & $\begin{array}{c}52 \pm 34 \\
47 \pm 6\end{array}$ & $\begin{array}{c}795 \pm 423 \\
470 \pm 98\end{array}$ & [11] \\
\hline CL & $\begin{array}{l}\text { experimental } \\
\text { IFBT }\end{array}$ & $\begin{array}{l}43.6 \pm 14.85 \\
43.11 \pm 4.15\end{array}$ & $\begin{aligned} 1074 & \pm 364 \\
708 & \pm 41\end{aligned}$ & $\begin{array}{l}\text { This } \\
\text { study }\end{array}$ \\
\hline
\end{tabular}

\section{Conclusions}

In this work, an experimental study on the tensile properties of Cola lepidota fibers was presented. The objective was to estimate the performance of these fibers available in Central, East and West African countries to increase their use for bio-based composite applications and to use the experimental methods widely described in the literature for plant fibers. The analysis of the tensile properties of single fibers shows the need to consider the intrinsic porosity of Cola lepidota fibers for the computation of the cross-section. The comparison of the tensile properties with those of others plant fibers shows the good performance of these fibers. Tensile tests performed on Cola lepidota fibers bundles thanks to the IFBT method allowed the influence of hackling step applied on these bundles to be studied. This step reduces shives and contributes to the parallelization of the bundles' fibers, and improves tensile properties. The properties identified experimentally and those predicted by the IFBT method are quite close, and the comparison with the data in the literature shows that Cola lepidota fibers have some tensile properties near those 
of flax, hemp and Kenaf. These results show that Cola lepidota fibers bundles or ribbons could be used as yarns/rovings without pre-treatments to weave some fabrics able to be used as reinforcements of composite materials. From this experimental study, future work at the scale of these Cola lepidota Fibers will focus on the close relationship between physicochemical properties and tensile behavior.

Author Contributions: Investigation: R.L.N.; writing—original draft preparation: R.L.N.; validation and supervision: D.S., M.F., A.R.L., J.A.A. and L.M.; writing-review and editing: D.S., M.F. and A.R.L. All authors have read and agreed to the published version of the manuscript.

Funding: This research received no external funding.

Data Availability Statement: Data are contained within the article.

Conflicts of Interest: The authors declare no conflict of interest.

\section{References}

1. Müssig, J.; Amaducci, S.; Bourmaud, A.; Beaugrand, J.; Shah, D.U. Transdisciplinary top-down review of hemp fibre composites: From an advanced product design to crop variety selection. Compos. Part C Open Access 2020, 2, 100010. [CrossRef]

2. Zhang, Z.; Cai, S.; Li, Y.; Wang, Z.; Long, Y.; Yu, T.; Shen, Y. High performances of plant fiber reinforced composites-A new insight from hierarchical microstructures. Compos. Sci. Technol. 2020, 194, 108151. [CrossRef]

3. Richely, E.; Bourmaud, A.; Placet, V.; Guessasma, S.; Beaugrand, J. A critical review of the ultrastructure, mechanics and modelling of flax fibres and their defects. Prog. Mater. Sci. 2021, 124, 100851. [CrossRef]

4. Chokshi, S.; Parmar, V.; Gohil, P.; Chaudhary, V. Chemical Composition and Mechanical Properties of Natural Fibers. Available online: https:/ / www.tandfonline.com/doi/full/10.1080/15440478.2020.1848738 (accessed on 10 October 2021).

5. Ramesh, M. Flax (Linum usitatissimum L.) fibre reinforced polymer composite materials: A review on preparation, properties and prospects. Prog. Mater. Sci. 2019, 102, 109-166. [CrossRef]

6. Bourmaud, A.; Beaugrand, J.; Shah, D.U.; Placet, V.; Baley, C. Towards the design of high-performance plant fibre composites. Prog. Mater. Sci. 2018, 97, 347-408. [CrossRef]

7. Sanivada, U.K.; Mármol, G.; Brito, F.P.; Fangueiro, R. PLA Composites Reinforced with Flax and Jute Fibers-A Review of Recent Trends, Processing Parameters and Mechanical Properties. Polymers 2020, 12, 2373. [CrossRef]

8. Mazian, B.; Bergeret, A.; Benezet, J.C.; Malhautier, L. Influence of field retting duration on the biochemical, microstructural, thermal and mechanical properties of hemp fibres harvested at the beginning of flowering. Ind. Crop. Prod. 2018, 116, 170-181. [CrossRef]

9. Müssig, J.; Haag, K.; Musio, S.; Bjelková, M.; Albrecht, K.; Uhrlaub, B.; Wang, S.; Wieland, H.J.; Amaducci, S. Biobased ‘Midperformance' composites using losses from the hackling process of long hemp-A feasibility study as part of the development of a biorefinery concept. Ind. Crop. Prod. 2020, 145, 111938. [CrossRef]

10. Grégoire, M.; Bar, M.; de Luycker, E.; Musio, S.; Amaducci, S.; Gabrion, X.; Placet, V.; Ouagne, P. Comparing flax and hemp fibres yield and mechanical properties after scutching/hackling processing. Ind. Crop. Prod. 2021, 172, 114045. [CrossRef]

11. Réquilé, S.; Mazian, B.; Grégoire, M.; Musio, S.; Gautreau, M.; Nuez, L.; Day, A.; Thiébeau, P.; Philippe, F.; Chabbert, B.; et al. Exploring the dew retting feasibility of hemp in very contrasting European environments: Influence on the tensile mechanical properties of fibres and composites. Ind. Crop. Prod. 2021, 164, 113337. [CrossRef]

12. Garat, W.; Corn, S.; Le Moigne, N.; Beaugrand, J.; Bergeret, A. Analysis of the morphometric variations in natural fibres by automated laser scanning: Towards an efficient and reliable assessment of the cross-sectional area. Compos. Part A Appl. Sci. Manuf. 2018, 108, 114-123. [CrossRef]

13. Summerscales, J.; Virk, A.S.; Hall, W. Fibre area correction factors (FACF) for the extended rules-of-mixtures for natural fibre reinforced composites. Mater. Today Proc. 2020, 31, S318-S320. [CrossRef]

14. Baley, C.; Gomina, M.; Breard, J.; Bourmaud, A.; Davies, P. Variability of mechanical properties of flax fibres for composite reinforcement. A review. Ind. Crop. Prod. 2020, 145, 111984. [CrossRef]

15. Bensadoun, F.; Verpoest, I.; Baets, J.; Müssig, J.; Graupner, N.; Davies, P.; Gomina, M.; Kervoelen, A.; Baley, C. Impregnated fibre bundle test for natural fibres used in composites. J. Reinf. Plast. Compos. 2017, 36, 942-957. [CrossRef]

16. Lefeuvre, A.; Bourmaud, A.; Lebrun, L.; Morvan, C.; Baley, C. A study of the yearly reproducibility of flax fiber tensile properties. Ind. Crop. Prod. 2013, 50, 400-407. [CrossRef]

17. Del Masto, A.; Trivaudey, F.; Guicheret-Retel, V.; Placet, V.; Boubakar, L. Investigation of the possible origins of the differences in mechanical properties of hemp and flax fibres: A numerical study based on sensitivity analysis. Compos. Part A Appl. Sci. Manuf. 2019, 124, 105488. [CrossRef]

18. Lefeuvre, A.; Bourmaud, A.; Morvan, C.; Baley, C. Elementary flax fibre tensile properties: Correlation between stress-strain behaviour and fibre composition. Ind. Crop. Prod. 2014, 52, 762-769. [CrossRef]

19. Sarasini, F.; Fiore, V. A systematic literature review on less common natural fibres and their biocomposites. J. Clean. Prod. 2018, 195, 240-267. [CrossRef] 
20. Jawaid, M.; Asim, M.; Tahir, P.M.; Nasir, M. Pineapple Leaf Fibers. Processing, Properties and Applications; Springer Nature Singapore Private Ltd.: Singapore, 2020. [CrossRef]

21. De Rosa, I.M.; Kenny, J.M.; Puglia, D.; Santulli, C.; Sarasini, F. Morphological, thermal and mechanical characterization of okra (Abelmoschus esculentus) fibres as potential reinforcement in polymer composites. Compos. Sci. Technol. 2010, 70, 116-122. [CrossRef]

22. Manimaran, P.; Prithiviraj, M.; Saravanakumar, S.S.; Arthanarieswaran, V.P.; Senthamaraikannan, P. Physicochemical, tensile, and thermal characterization of new natural cellulosic fibers from the stems of Sida cordifolia. J. Nat. Fibers 2017, 15, 860-869. [CrossRef]

23. Fiore, V.; Scalici, T.; Valenza, A. Characterization of a new natural fiber from Arundo donax L. as potential reinforcement of polymer composites. Carbohydr. Polym. 2014, 106, 77-83. [CrossRef]

24. Belouadah, Z.; Ati, A.; Rokbi, M. Characterization of new natural cellulosic fiber from Lygeum spartum L. Carbohydr. Polym. 2015, 134, 429-437. [CrossRef]

25. Jebadurai, S.G.; Raj, R.E.; Sreenivasan, V.S.; Binoj, J.S. Comprehensive characterization of natural cellulosic fiber from Coccinia grandis stem. Carbohydr. Polym. 2018, 207, 675-683. [CrossRef]

26. Gopinath, R.; Billigraham, P.; Sathishkumar, T.P. Physicochemical and Thermal Properties of New Cellulosic Fiber Obtained from the Stem of Markhamia lutea. Available online: https://www.tandfonline.com/doi/abs/10.1080/15440478.2021.1964133 (accessed on 15 October 2021).

27. Gopinath, R.; Billigraham, P.; Sathishkumar, T.P. Characterization Studies on New Natural Cellulosic Fiber Extracted from the Bark of Erythrina variegata. Available online: https://www.tandfonline.com/doi/abs/10.1080/15440478.2021.1961344 (accessed on 15 October 2021).

28. Gopinath, R.; Billigraham, P.; Sathishkumar, T.P. Physicochemical and Thermal Properties of Cellulosic Fiber Extracted from the Bark of Albizia Saman. Available online: https:/ / www.tandfonline.com/doi/abs/10.1080/15440478.2021.1929654 (accessed on 15 October 2021).

29. Okonkwo, E.G.; Daniel-Mkpume, C.C.; Ude, S.N.; Onah, C.C.; Ijomah, A.I.; Omah, A.D. Chicken feather fiber-African star apple leaves bio-composite: Empirical study of mechanical and morphological properties. Mater. Res. Express 2019, 6, 105361. [CrossRef]

30. Mewoli, A.E.; Segovia, C.; Ebanda, F.B.; Ateba, A.; Noah, P.M.A.; Ndiwe, B.; Njom, A.E. Physical-Chemical and Mechanical Characterization of the Bast Fibers of Triumfetta cordifolia A.Rich. from the Equatorial Region of Cameroon. J. Miner. Mater. Charact. Eng. 2020, 8, 163-176. [CrossRef]

31. Béakou, A.; Ntenga, R.; Lepetit, J.; Atéba, J.A.; Ayina, L. Physico-chemical and microstructural characterization of "Rhectophyllum camerunense" plant fiber. Compos. Part A Appl. Sci. Manuf. 2008, 39, 67-74. [CrossRef]

32. Noutegomo, B.; Ebanda, F.B.; Ateba, A. Study of the diffusion behavior of water vapor sorption in natural fiber composite: Plaster/Rhecktophyllum camerunense. MOJ Appl. Bionics Biomech. 2019, 3, 12-16. [CrossRef]

33. Betene, A.D.O.; Betene, F.E.; Martoïa, F.; Dumont, P.J.; Atangana, A.; Noah, P.M.A. Physico-Chemical and Thermal Characterization of Some Lignocellulosic Fibres: Ananas comosus (AC), Neuropeltis acuminatas (NA) and Rhecktophyllum camerunense (RC). J. Miner. Mater. Charact. Eng. 2020, 8, 205-222. [CrossRef]

34. FAO. Rapport sur les forêts 2011: La Situation des Forêts dans le Bassin Amazonien, le Bassin du Congo et l'Asie du Sud-Est; FAO: Brazzaville, Congo, 2011.

35. Ndoumou, B.R.L.; Mevaa, L.; Ouagne, P.; Ebanda, F.B.; Noah, P.M.A.; Ateba, J.A. Physico-Chemical and Thermal Characterization of a Lignocellulosic Fiber, Extracted from the Bast of Cola lepidota Stem. J. Miner. Mater. Charact. Eng. 2020, 8, 377-392. [CrossRef]

36. Vivien, J.; Faure, J.J. Fruitiers Sauvages d'Afrique-Espèces du Cameroun; Nguila-Kerou, Ed.; Editions Nguila-Kerou: Clohars-Carnoet, France, 1995; p. 416.

37. Zafeiropoulos, N.E.; Baillie, C.A. A study of the effect of surface treatments on the tensile strength of flax fibres: Part II. Application of Weibull statistics. Compos. Part A Appl. Sci. Manuf. 2007, 38, 629-638. [CrossRef]

38. European Linen \& Hemp. Available online: www.mastersoflinen.com/ (accessed on 20 October 2021).

39. Corbin, A.C.; Sala, B.; Soulat, D.; Ferreira, M.; Labanieh, A.R.; Placet, V. Development of quasi-unidirectional fabrics with hemp fiber: A competitive reinforcement for composite materials. J. Compos. Mater. 2020, 55, 551-564. [CrossRef]

40. Virk, A.S.; Hall, W.; Summerscales, J. Modulus and strength prediction for natural fibre composites. Mater. Sci. Technol. 2012, 28, 864-871. [CrossRef]

41. Shah, D.U.; Schubel, P.J.; Clifford, M.J. Modelling the effect of yarn twist on the tensile strength of unidirectional plant fibre yarn composites. J. Compos. Mater. 2013, 47, 425-436. [CrossRef]

42. Madsen, B.; Thygesen, A.; Lilholt, H. Plant fibre composites-Porosity and stiffness. Compos. Sci. Technol. 2009, 69, 1057-1069. [CrossRef]

43. Haag, K.; Padovani, J.; Fita, S.; Trouvé, J.-P.; Pineau, C.; Hawkins, S.; de Jong, H.; Deyholos, M.K.; Chabbert, B.; Müssig, J.; et al. Influence of flax fibre variety and year-to-year variability on composite properties. Ind. Crop. Prod. 2017, 98, 1-9. [CrossRef]

44. Placet, V.; Cissé, O.; Boubakar, L. Nonlinear tensile behaviour of elementary hemp fibres. Part I: Investigation of the possible origins using repeated progressive loading with in situ microscopic observations. Compos. Part A Appl. Sci. Manuf. 2014, 56, 319-327. [CrossRef]

45. Trujillo, E.; Moesen, M.; Osorio, L.; van Vuure, A.; Ivens, J.; Verpoest, I. Bamboo fibres for reinforcement in composite materials: Strength Weibull analysis. Compos. Part A Appl. Sci. Manuf. 2014, 61, 115-125. [CrossRef] 
46. Ntenga, R.; Saïdjo, S.; Beda, T.; Béakou, A. Beda Estimation of the Effects of the Cross-Head Speed and Temperature on the Mechanical Strength of Kenaf Bast Fibers Using Weibull and Monte-Carlo Statistics. Fibers 2019, 7, 89. [CrossRef]

47. Wang, C.; Bai, S.; Yue, X.; Long, B.; Choo-Smith, L.P. Relationship between chemical composition, crystallinity, orientation and tensile strength of kenaf fiber. Fibers Polym. 2016, 17, 1757-1764. [CrossRef]

48. Nuez, L. Contribution to the Multi-Scale Study of Elementary Flax Fibres and Xylem for Composite material Reinforcement. Ph.D. Thesis, University of Southern Brittany, Lorient, France, 2021.

49. Thyavihalli Girijappa, Y.G.; Mavinkere Rangappa, S.; Parameswaranpillai, J.; Siengchin, S. Natural Fibers as Sustainable and Renewable Resource for Development of Eco-Friendly Composites: A Comprehensive Review. Front. Mater. 2019, 6, 226. [CrossRef]

50. Samouh, Z.; Cherkaoui, O.; Soulat, D.; Labanieh, A.; Boussu, F.; Moznine, R. Identification of the Physical and Mechanical Properties of Moroccan Sisal Yarns Used as Reinforcements for Composite Materials. Fibers 2021, 9, 13. [CrossRef]

51. Lansiaux, H.; Soulat, D.; Boussu, F.; Labanieh, A.R. Development and Multiscale Characterization of 3D Warp Interlock Flax Fabrics with Different Woven Architectures for Composite Applications. Fibers 2020, 8, 15. [CrossRef]

52. Lecoublet, M.; Khennache, M.; Leblanc, N.; Ragoubi, M.; Poilâne, C. Physico-mechanical performances of flax fiber biobased composites: Retting and process effects. Ind. Crop. Prod. 2021, 173, 114110. [CrossRef]

53. Sala, B.; Gabrion, X.; Trivaudey, F.; Guicheret-Retel, V.; Placet, V. Influence of the stress level and hygrothermal conditions on the creep/recovery behaviour of high-grade flax and hemp fibre reinforced GreenPoxy matrix composites. Compos. Part A Appl. Sci. Manuf. 2021, 141, 106204. [CrossRef]

54. Charlet, K.; Jernot, J.P.; Gomina, M.; Bizet, L.; Bréard, J. Mechanical Properties of Flax Fibers and of the Derived Unidirectional Composites. J. Compos. Mater. 2010, 44, 2887-2896. [CrossRef]

55. Shah, D.U.; Nag, R.K.; Clifford, M.J. Why do we observe significant differences between measured and 'back-calculated' properties of natural fibres? Cellulose 2016, 23, 1481-1490. [CrossRef] 